\title{
Effects of $\mathrm{MgCl}_{2}$ solution pretreatment at room temperature on the pyrolysis behavior of pubescens and the properties of bio-oil obtained
}

Yichen Liu, Yue Wang, Wenli Wang, Longfei Liu, Changwei Hu*

Key Laboratory of Green Chemistry and Technology, Ministry of Education, College

of Chemistry, Sichuan University, 29 Wangjiang Road, Chengdu, Sichuan 610064, P.

R. China

Corresponding Author

*E-mail: changweihu@scu.edu.cn

Supporting Information 


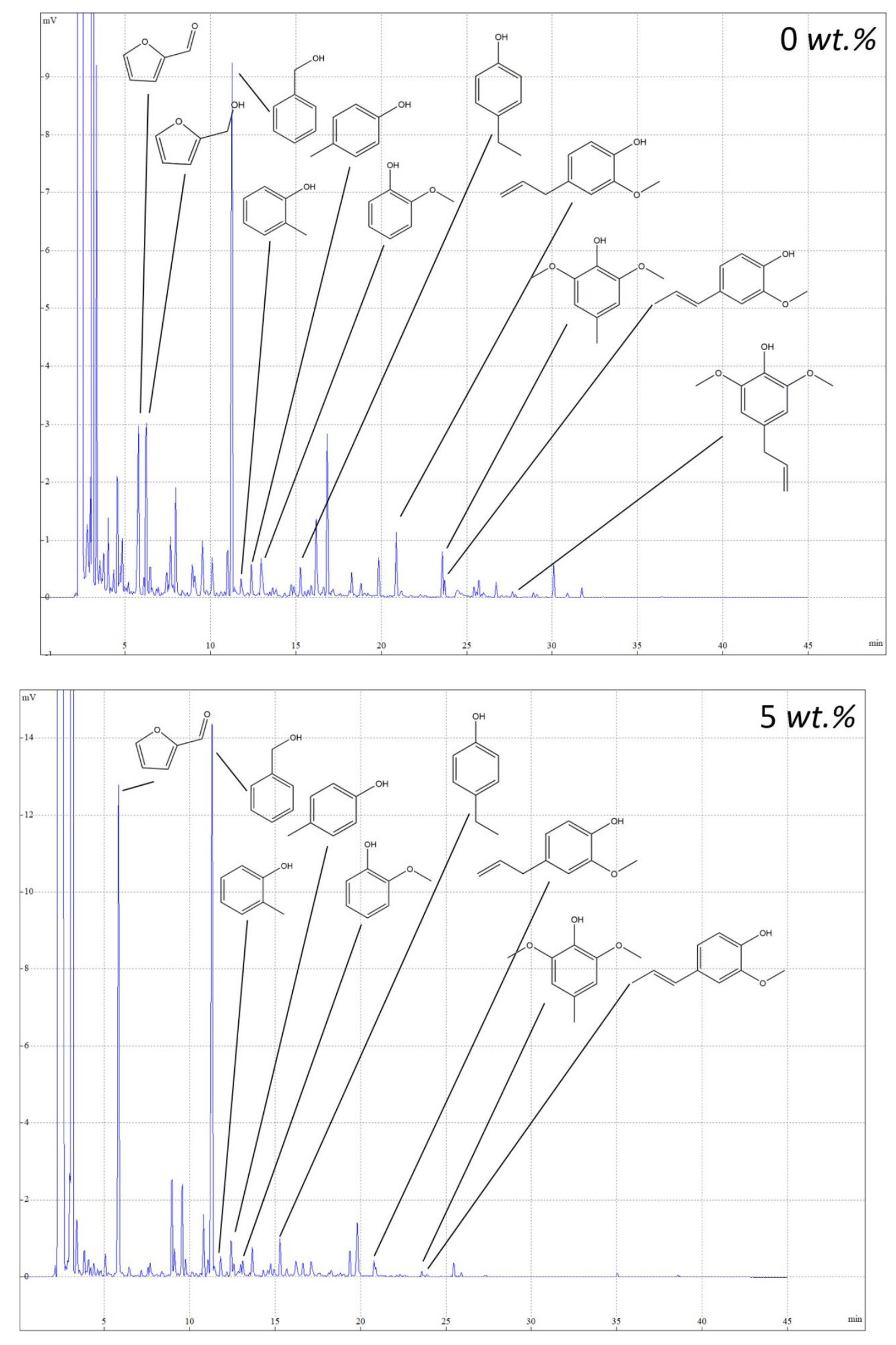



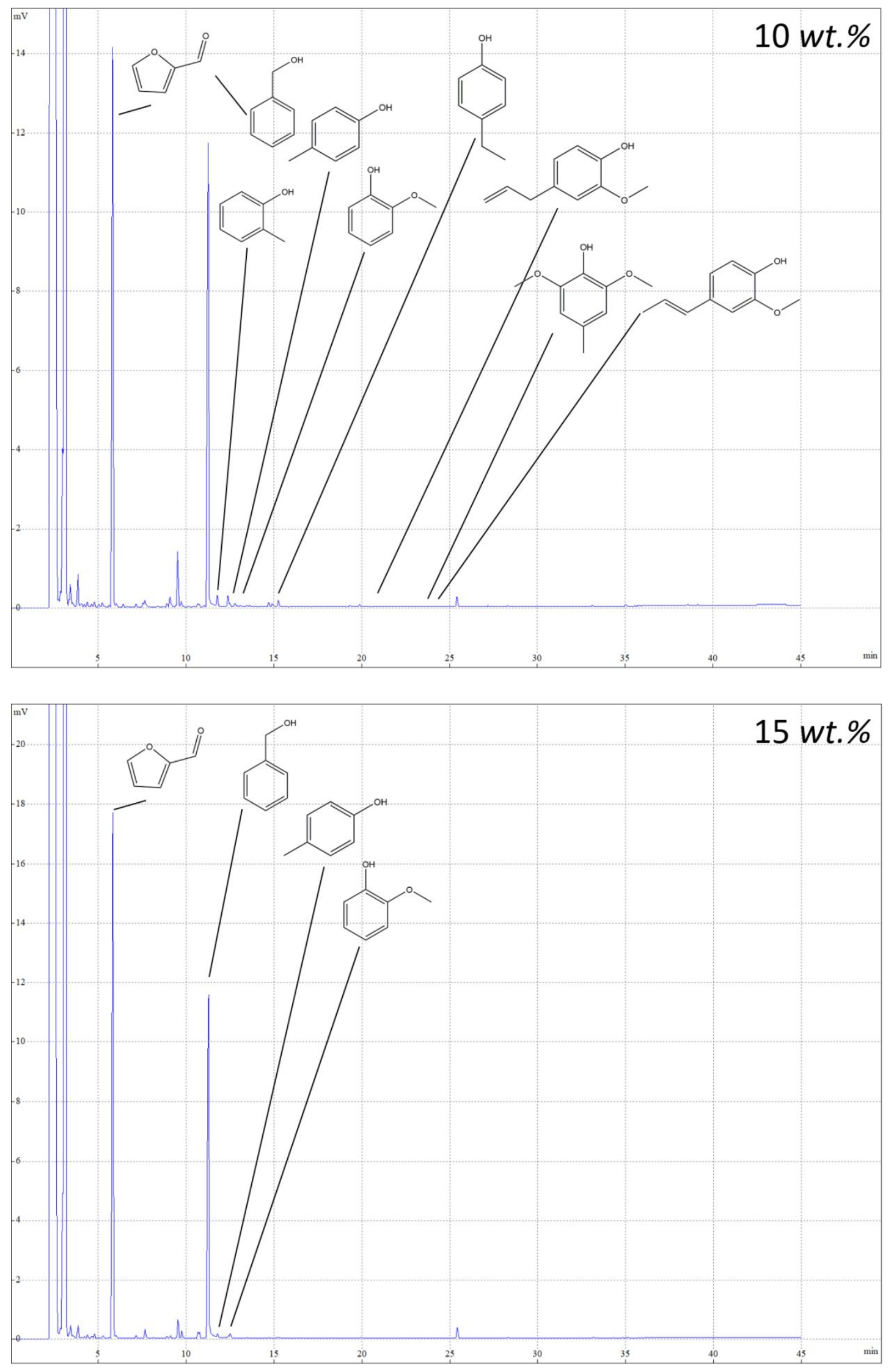

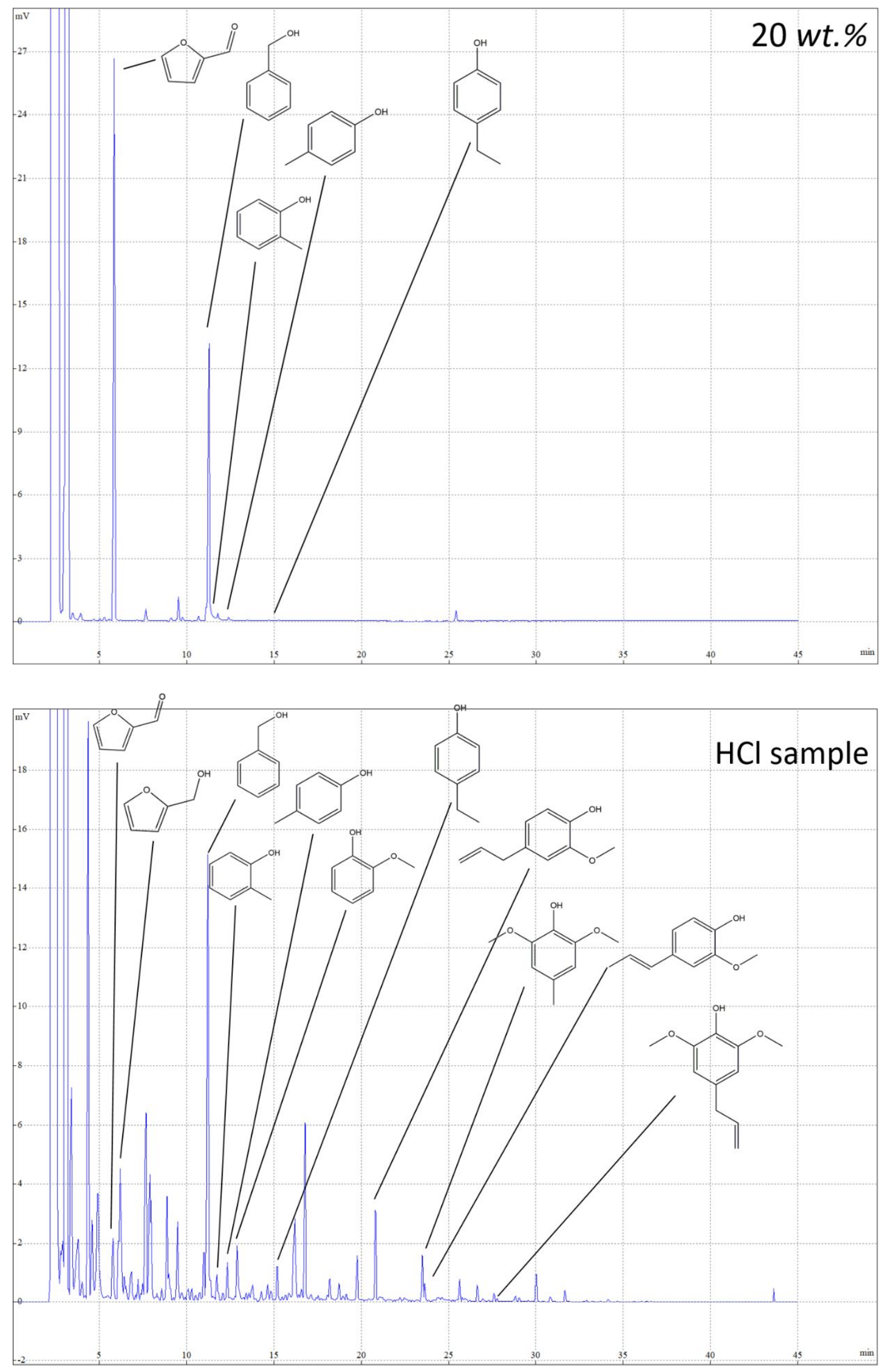


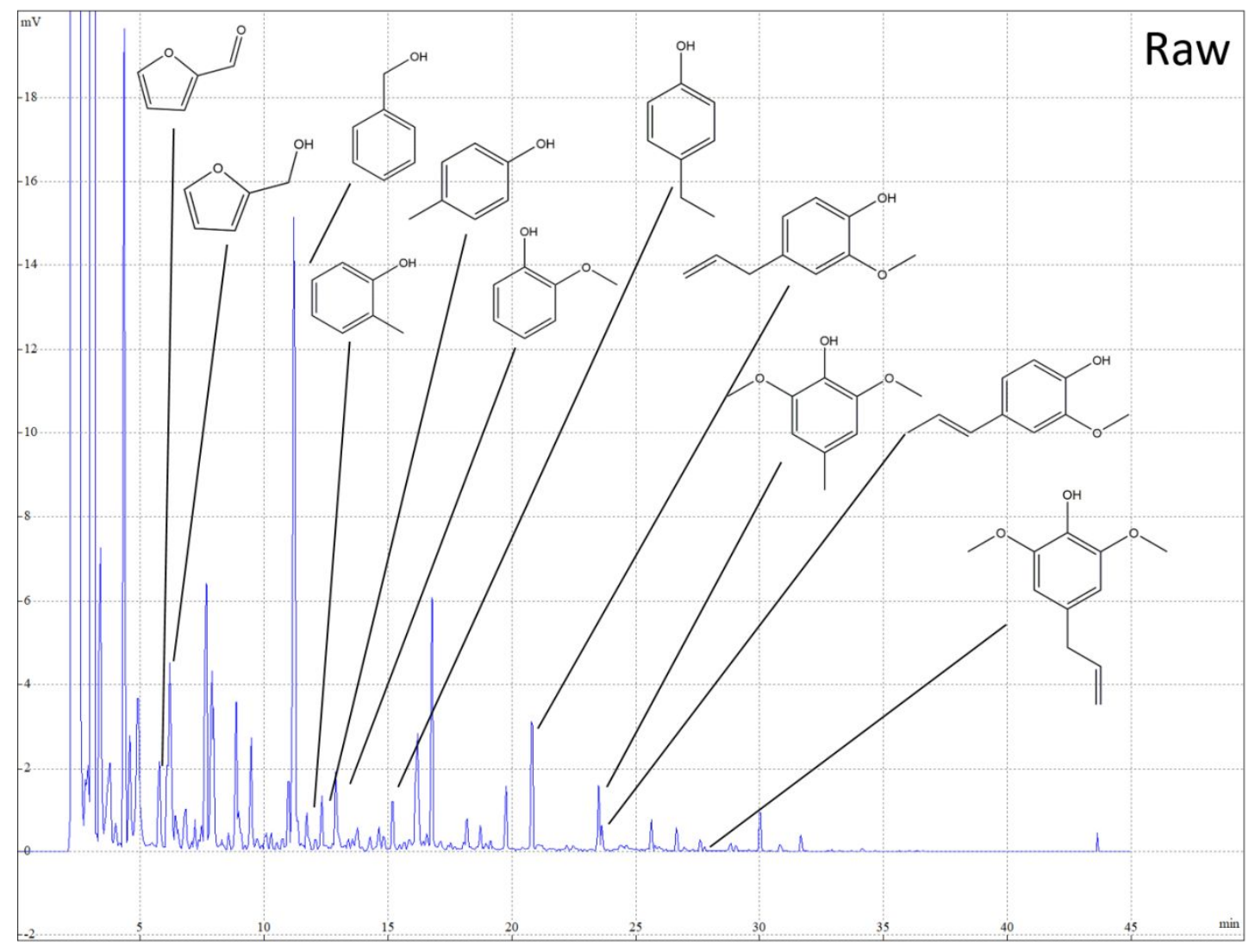

Figure S1. Original spectra of GC-FID. 


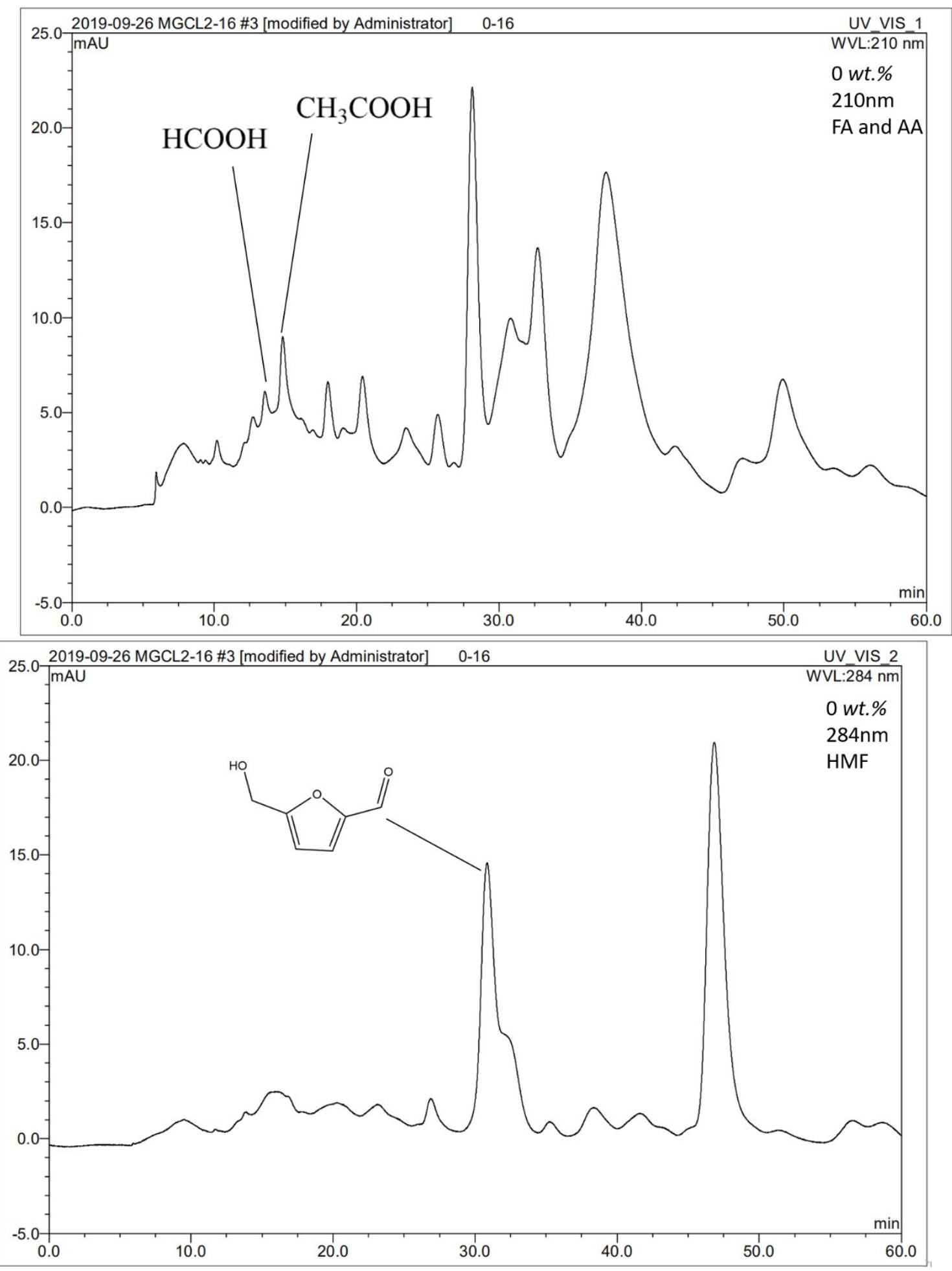




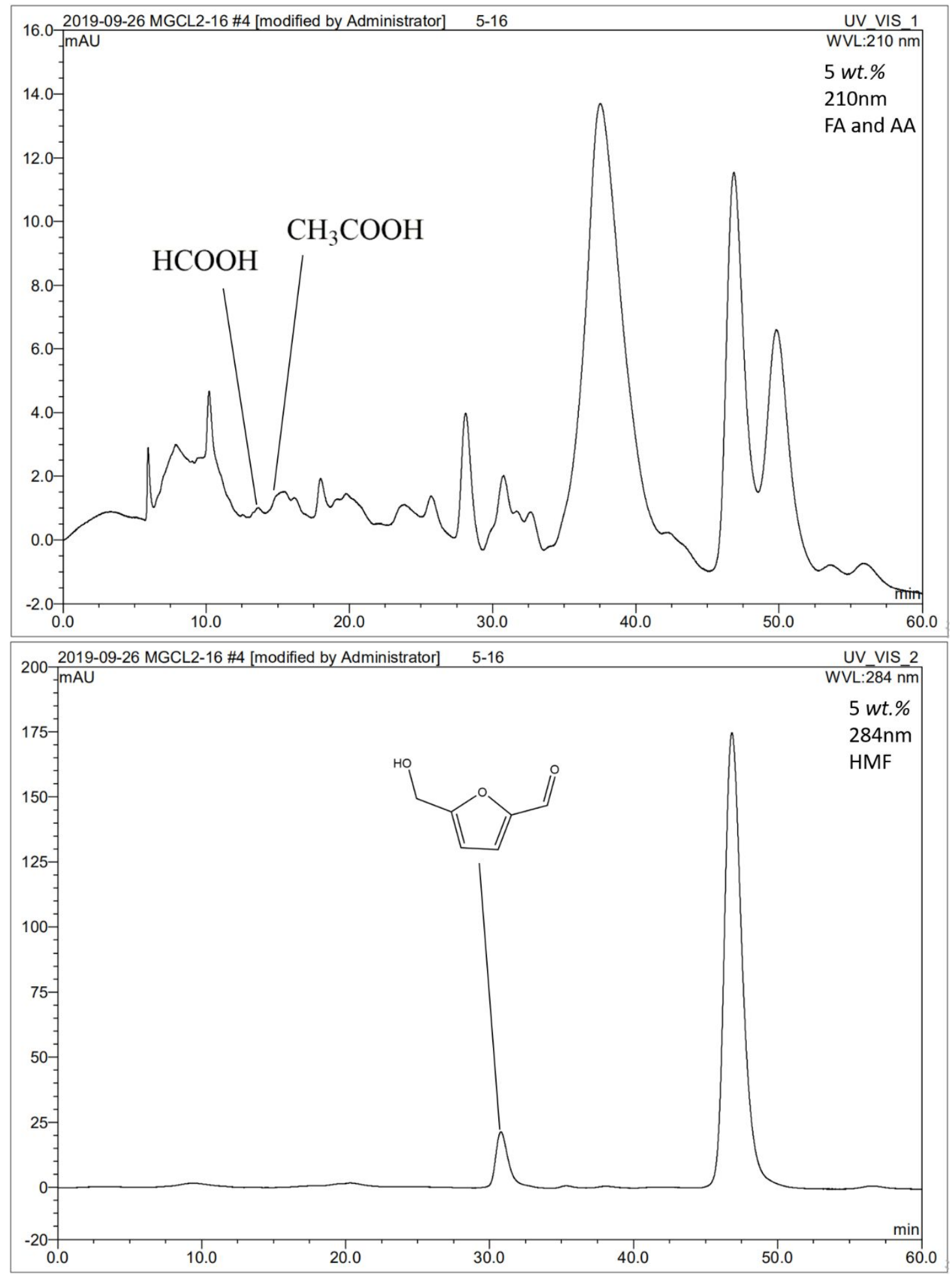



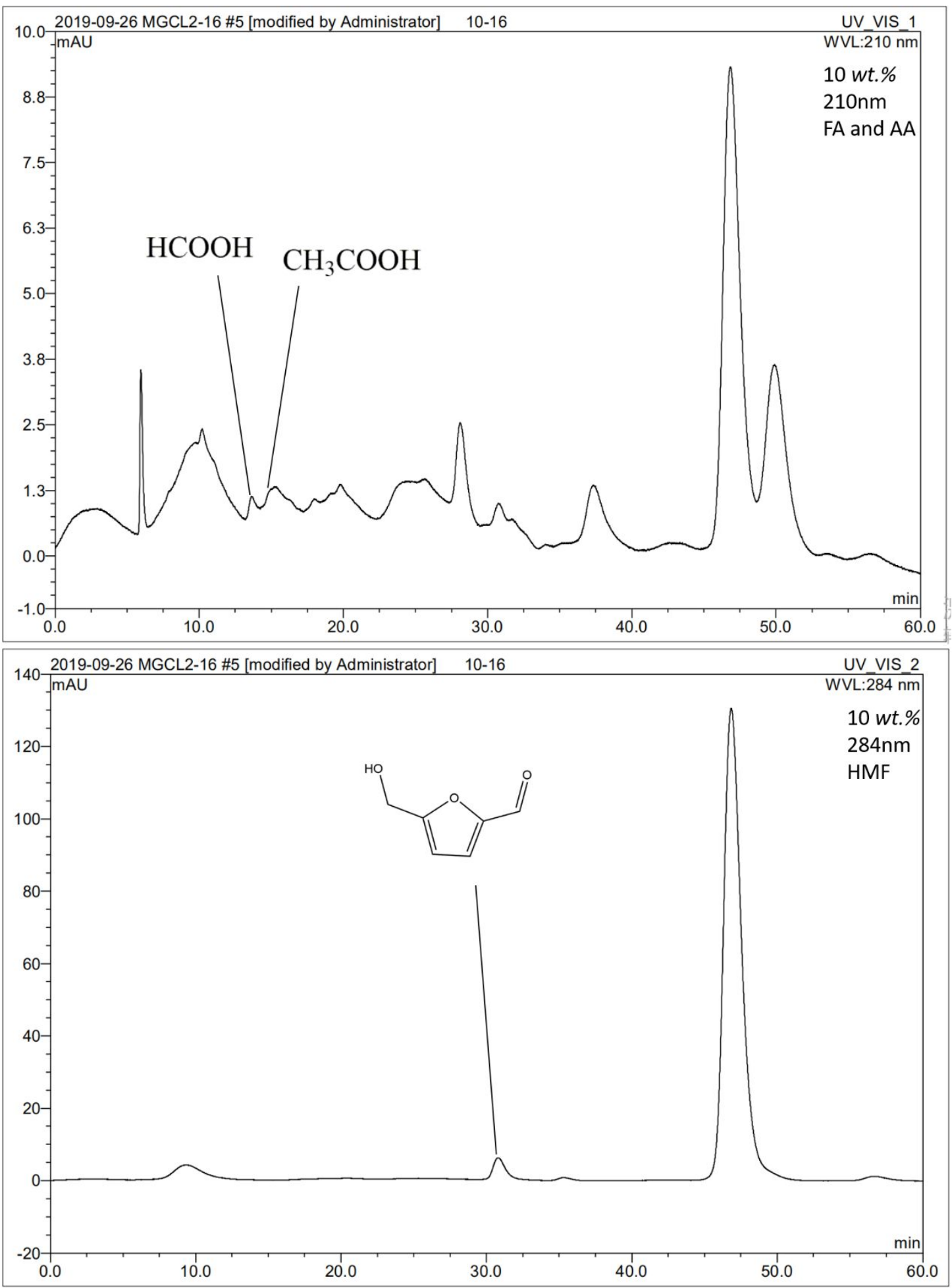


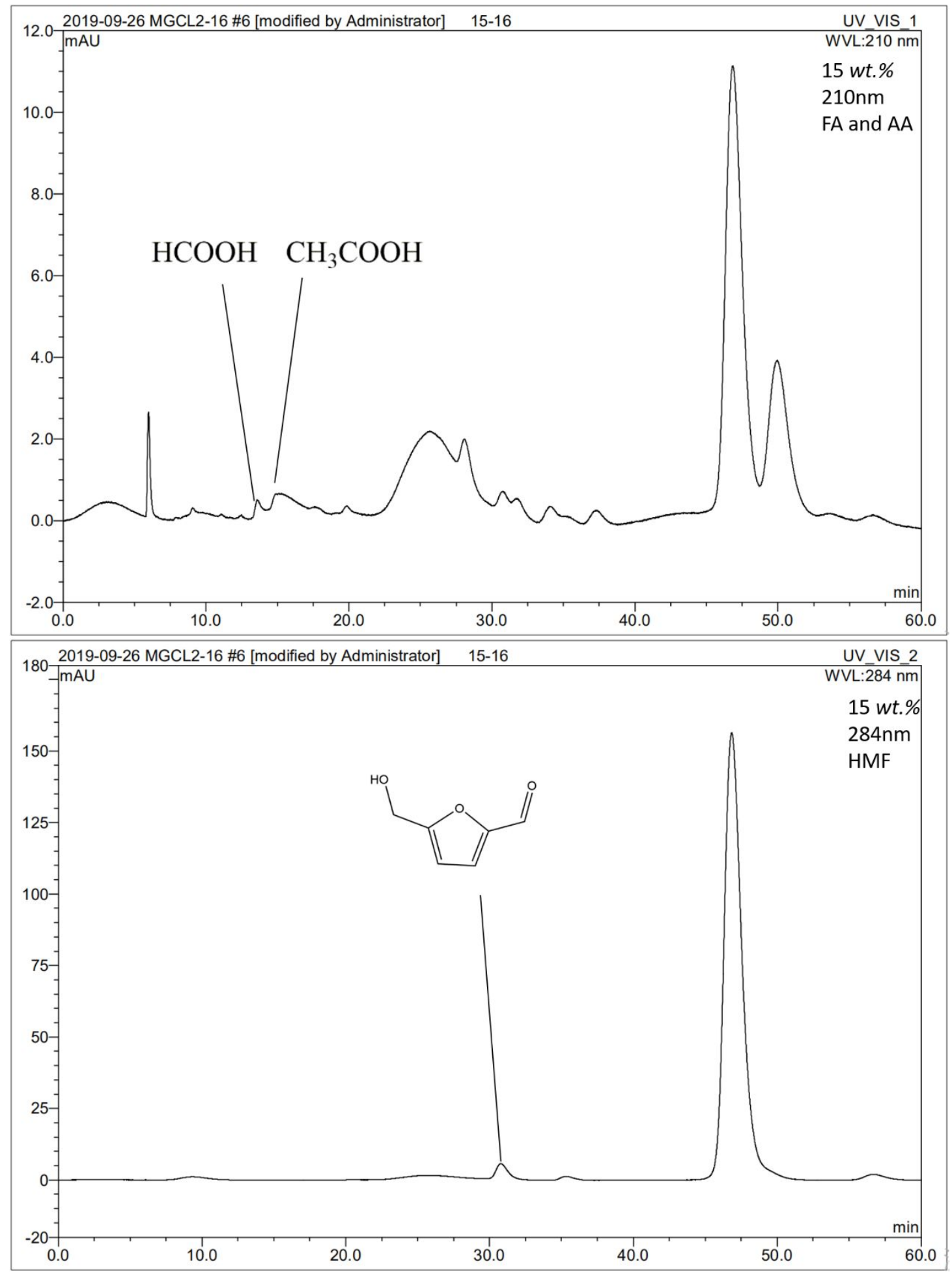




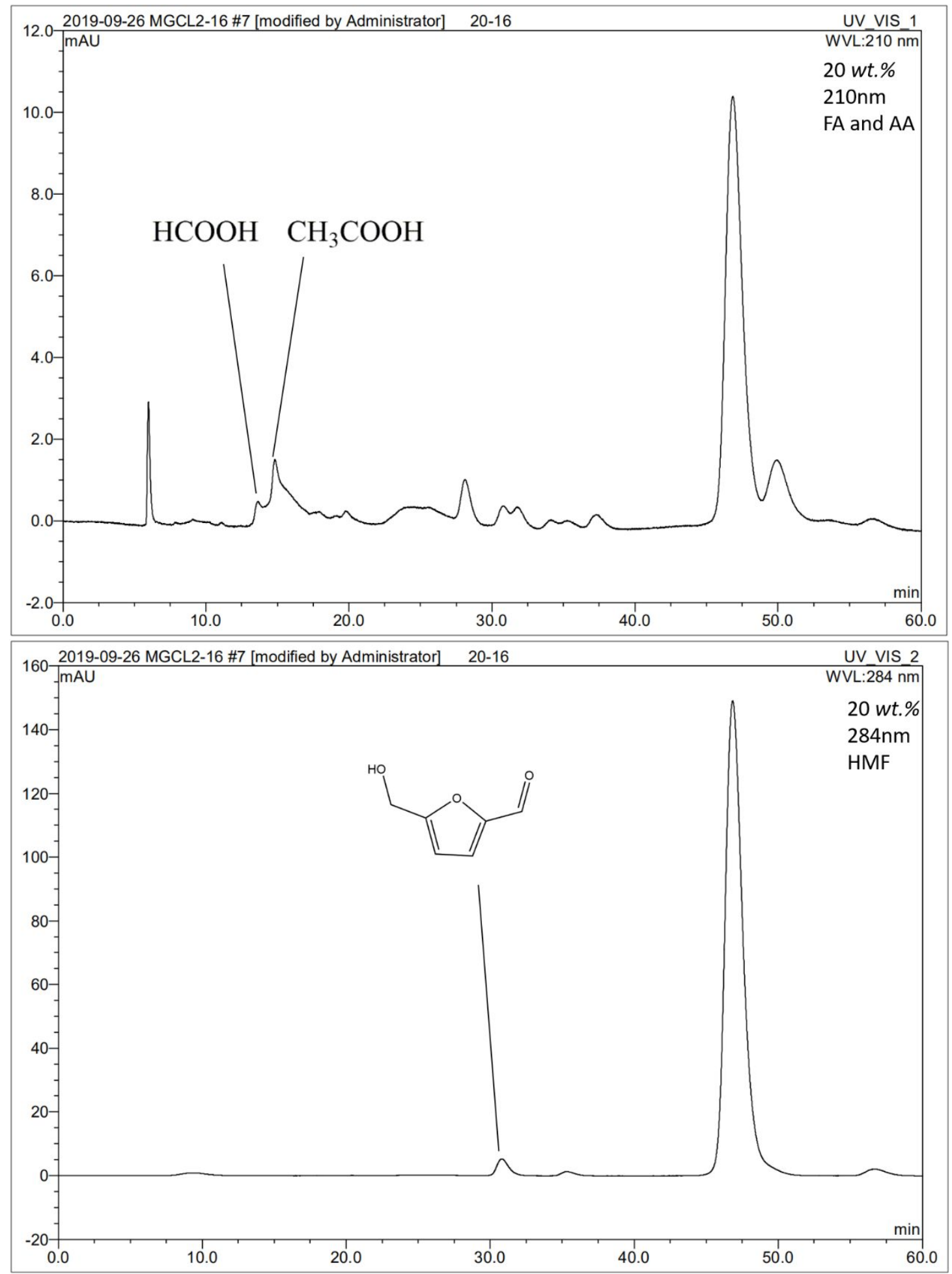



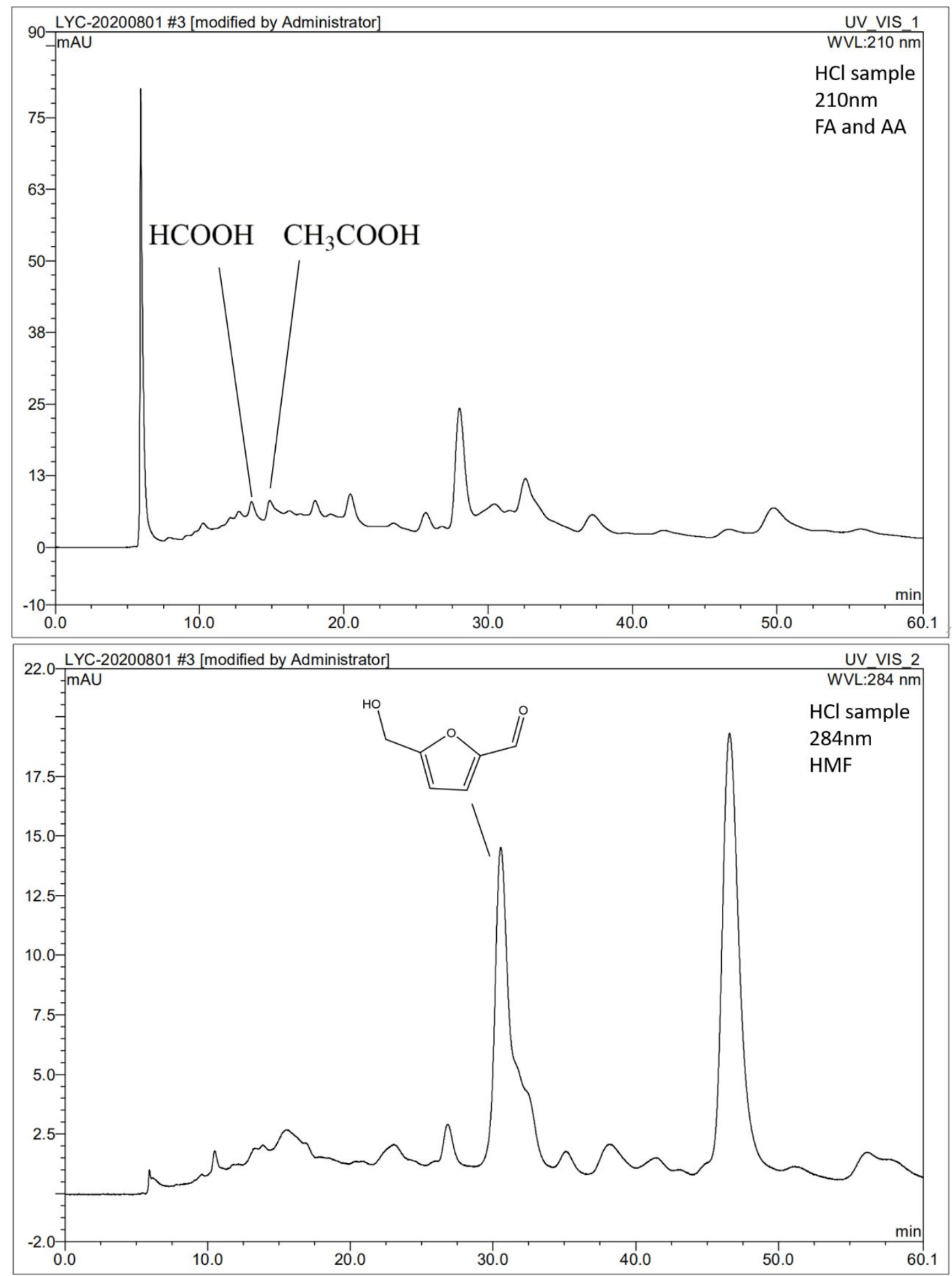

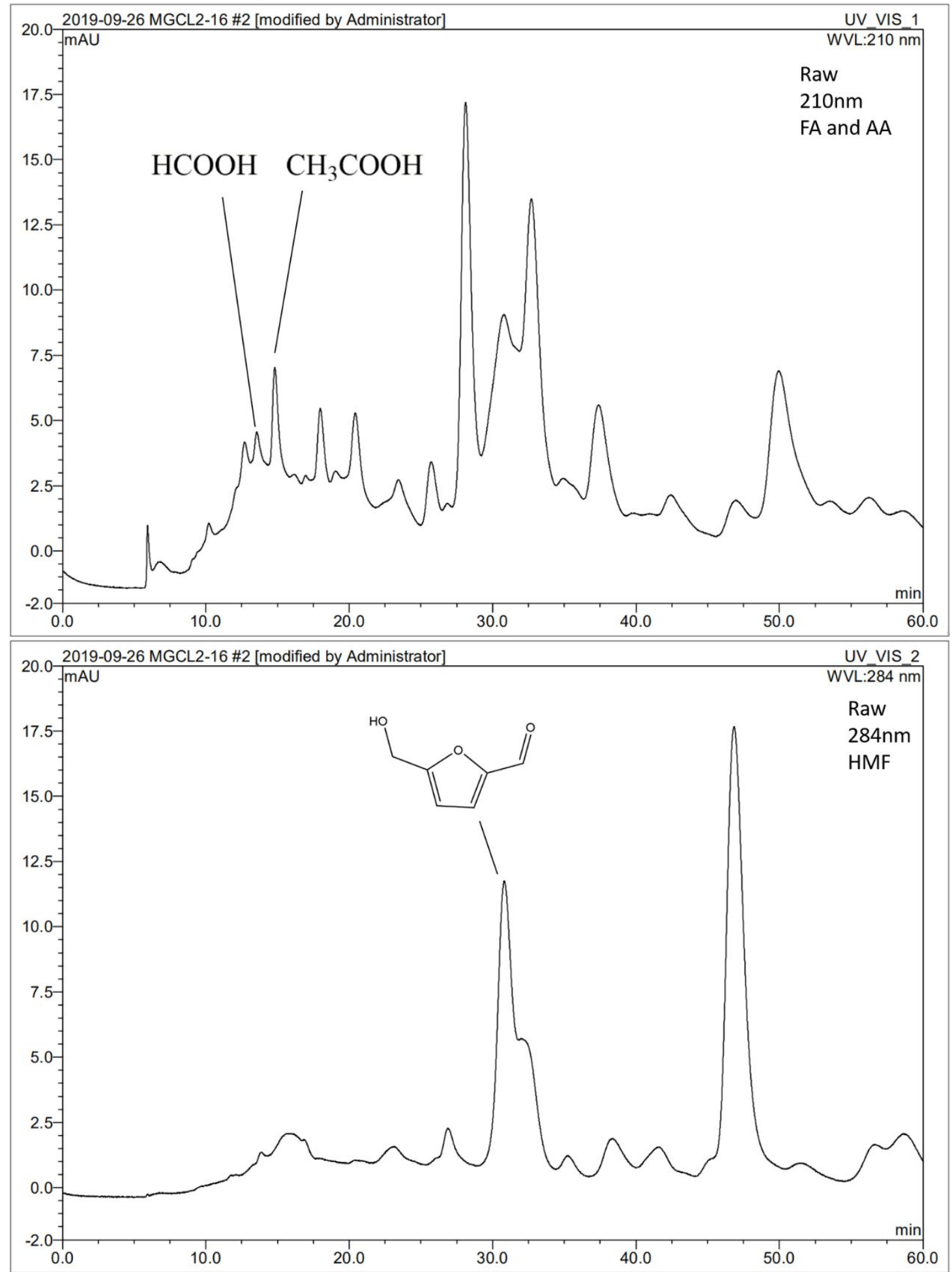

Figure S2. Original spectra of HPLC. 


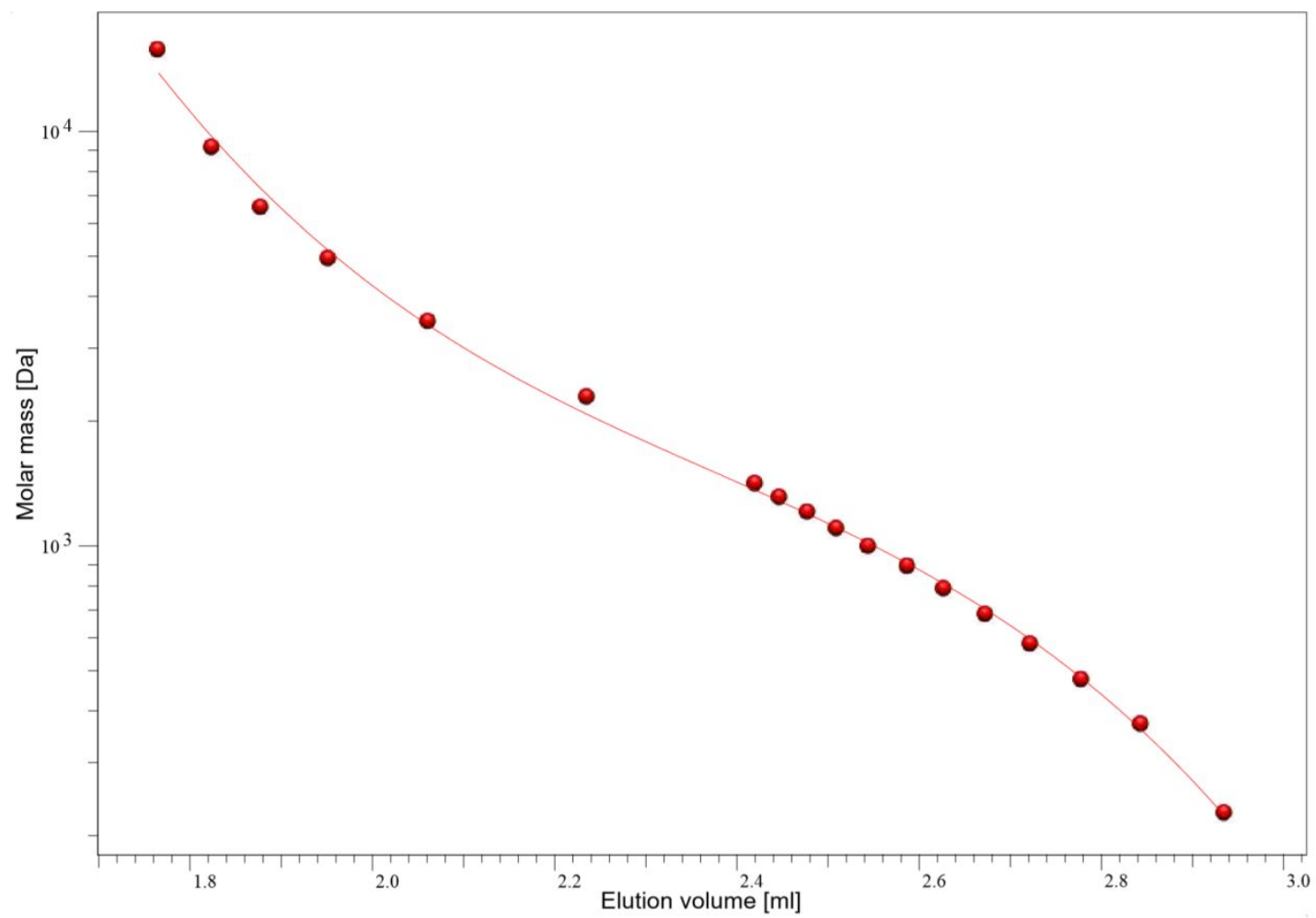

Figure S3. Calibration curve of GPC.

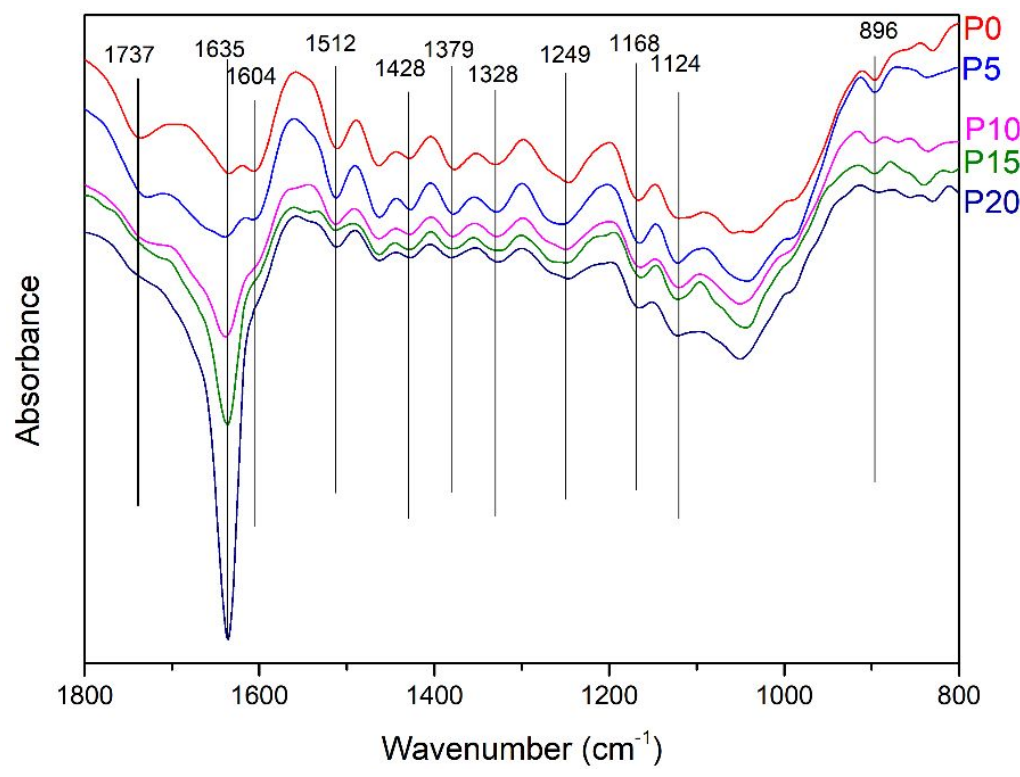

Figure S4. The FT-IR spectra ranging from $1800 \mathrm{~cm}^{-1}$ to $800 \mathrm{~cm}^{-1}$ of raw and pretreated pubescens samples. 


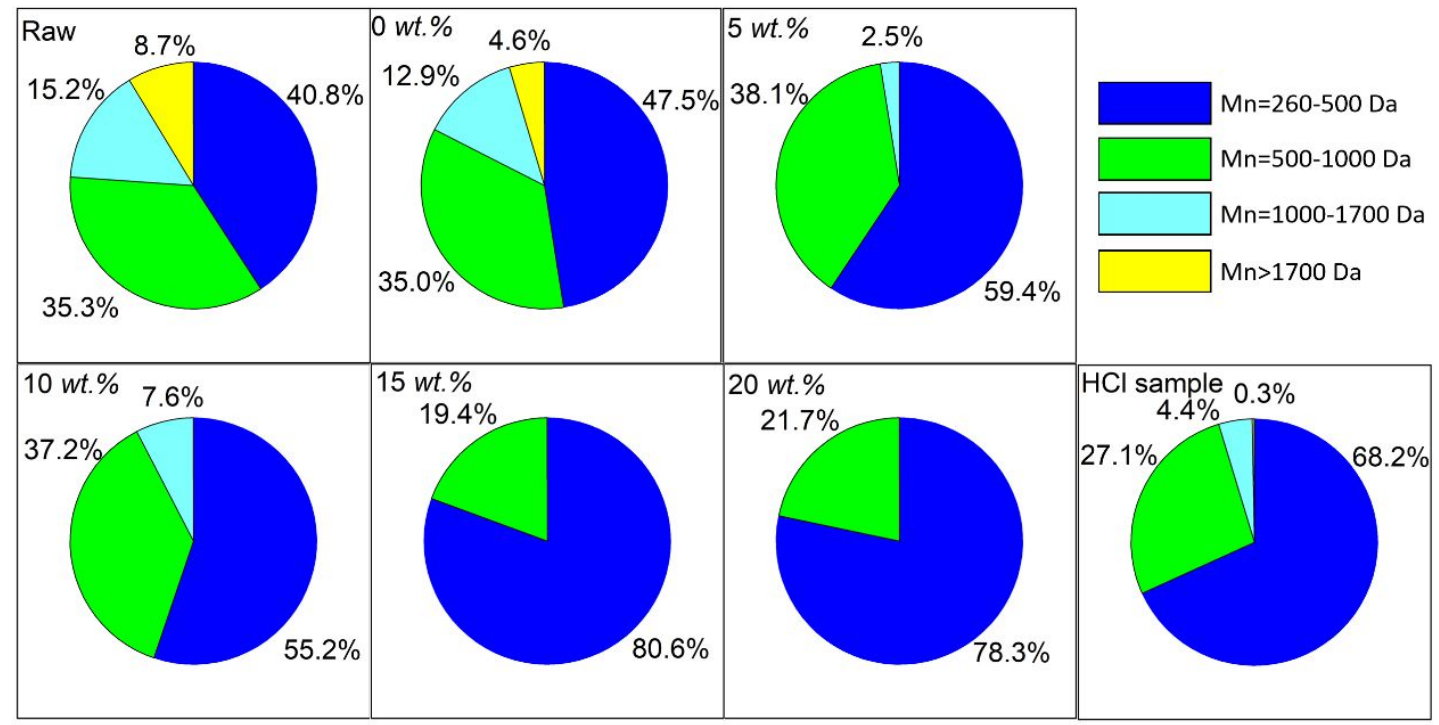

Figure S5. Molecular weight distribution of bio-oil obtained from pyrolysis of pubescen samples (the pretreated and the untreated). 


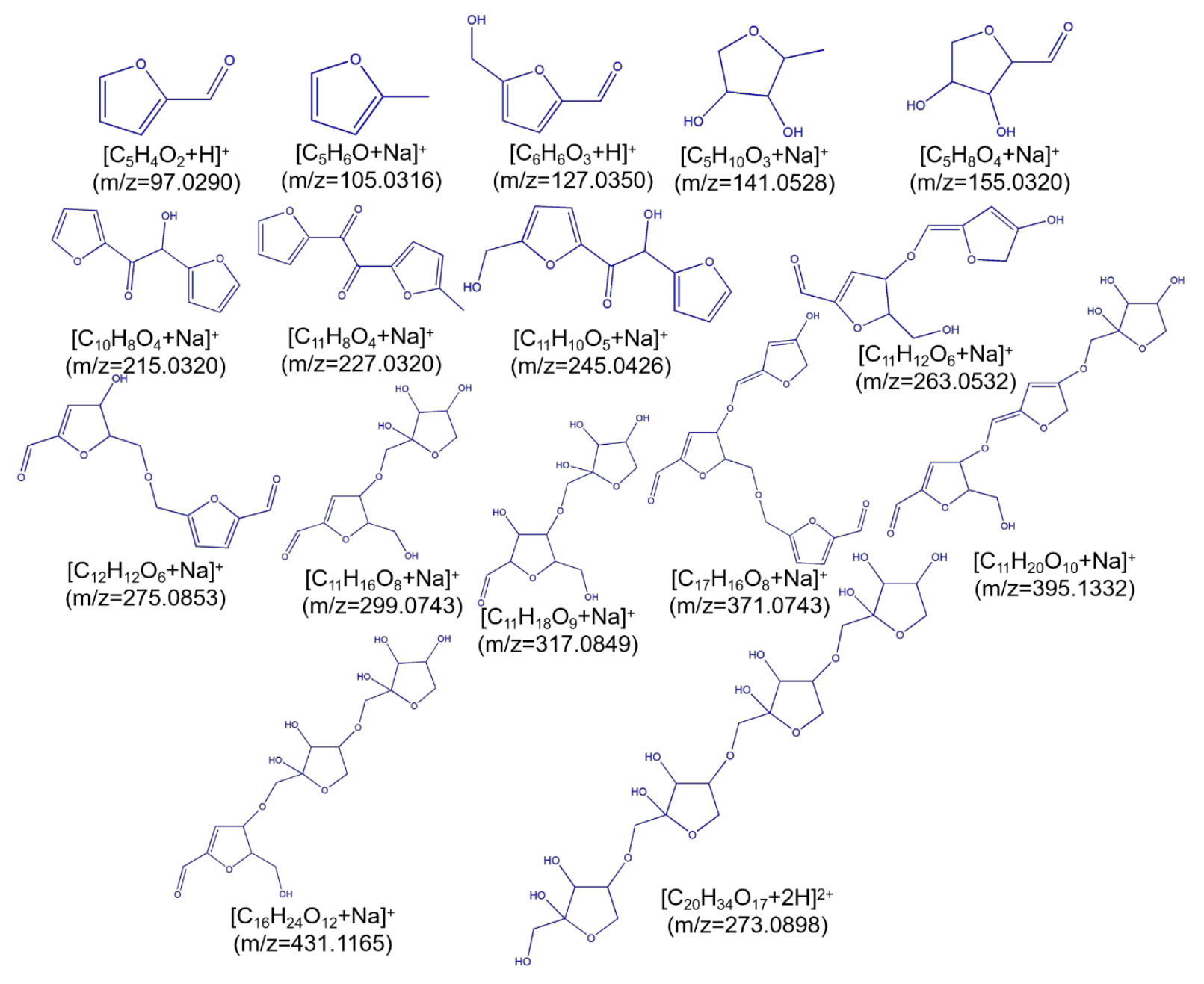

Figure S6. Holocellulose-derived compounds detected from ESI-MS spectra. 
<smiles>Oc1ccccc1</smiles><smiles>COc1cc(CO)cc(O)c1O</smiles><smiles>COc1cc(CC=O)cc(O)c1O</smiles><smiles>COc1cc(C(C)=O)cc2ccoc12</smiles><smiles>O=CC=C(O)c1cc(O)c2ccccc2c1</smiles>

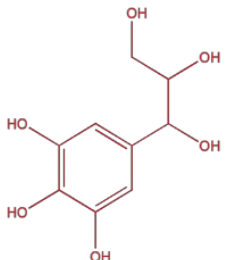

$\left[\mathrm{C}_{6} \mathrm{H}_{6} \mathrm{O}+\mathrm{H}\right]^{+}$

$\left[\mathrm{C}_{8} \mathrm{H}_{10} \mathrm{O}_{4}+\mathrm{H}\right]^{+} \quad\left[\mathrm{C}_{9} \mathrm{H}_{10} \mathrm{O}_{4}+\mathrm{H}\right]^{+} \quad\left[\mathrm{C}_{11} \mathrm{H}_{10} \mathrm{O}_{3}+\mathrm{H}\right]^{+}$

$\left[\mathrm{C}_{11} \mathrm{H}_{8} \mathrm{O}_{4}+\mathrm{H}\right]^{+}$

$\mathrm{C}_{9} \mathrm{H}_{12} \mathrm{O}_{6}+\mathrm{H}^{+}$ $(\mathrm{m} / \mathrm{z}=95.0452) \quad(\mathrm{m} / \mathrm{z}=171.0634)(\mathrm{m} / \mathrm{z}=183.0695) \quad(\mathrm{m} / \mathrm{z}=191.0630)(\mathrm{m} / \mathrm{z}=205.0423)(\mathrm{m} / \mathrm{z}=217.0850)$<smiles>COc1cc(C(O)CC=O)cc(OC)c1O</smiles>

$\left[\mathrm{C}_{11} \mathrm{H}_{14} \mathrm{O}_{5}+\mathrm{H}\right]^{+}$ $(\mathrm{m} / \mathrm{z}=227.0841)$
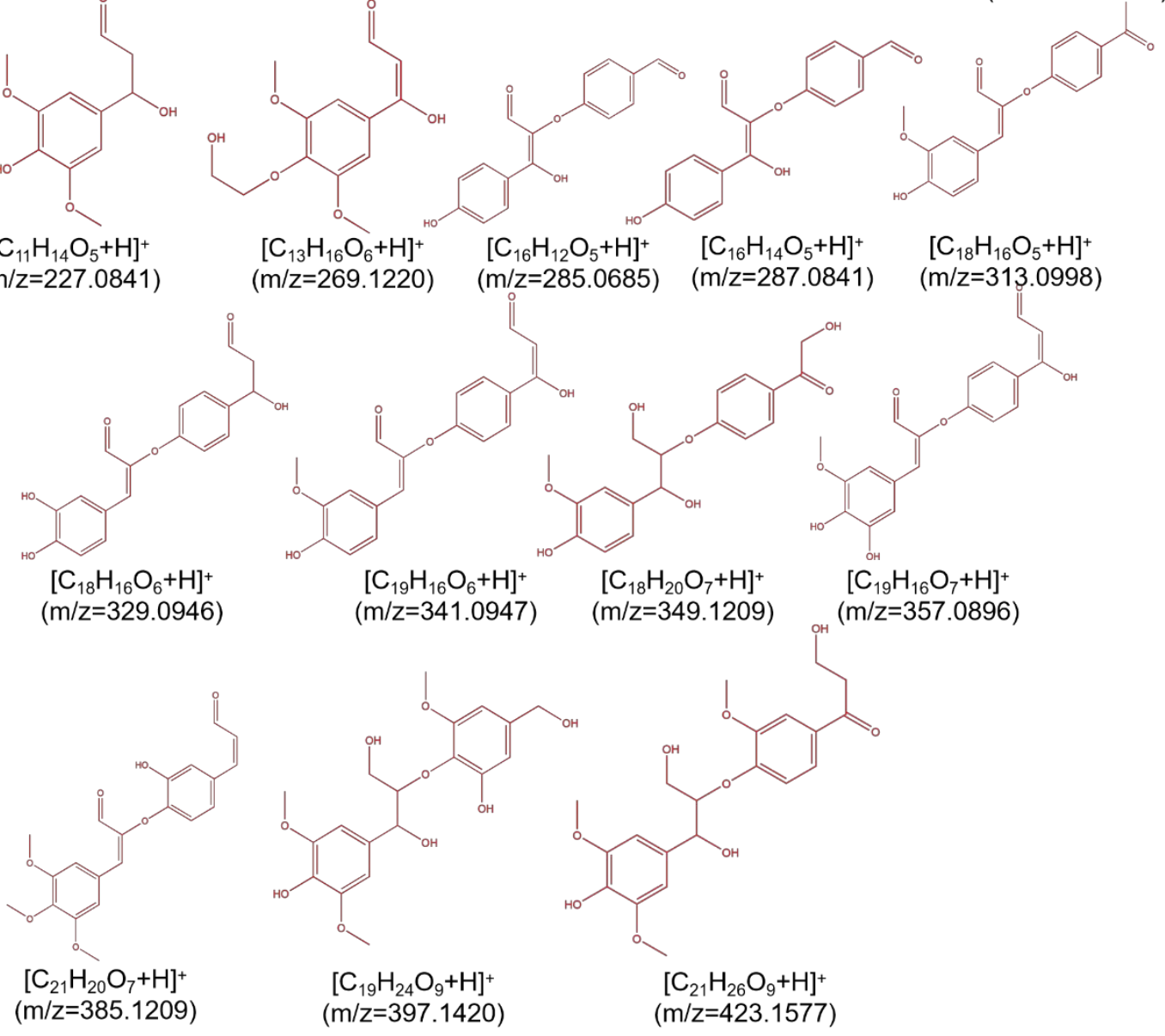

Figure S7. Lignin-derived compounds detected from ESI-MS spectra. 


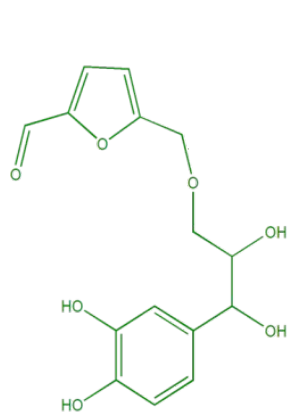

$\left[\mathrm{C}_{15} \mathrm{H}_{16} \mathrm{O}_{7}+\mathrm{H}\right]^{+}$ (m/z=309.0974)

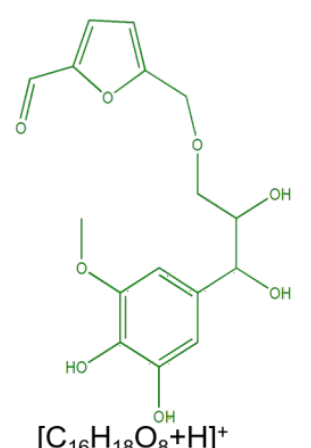

$\left[\mathrm{C}_{16} \mathrm{H}_{18} \mathrm{O}_{8}+\mathrm{H}\right]^{+}$ $(\mathrm{m} / \mathrm{z}=339.1080)$

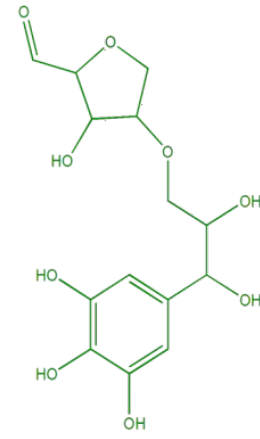

$\left[\mathrm{C}_{14} \mathrm{H}_{18} \mathrm{O}_{8}+\mathrm{H}\right]^{+}$ $(\mathrm{m} / \mathrm{z}=315.1080)$

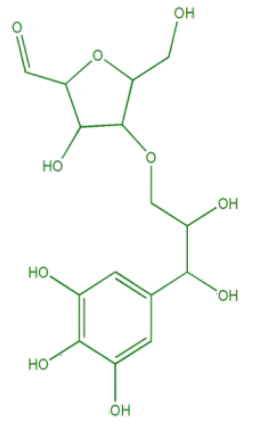

$\left[\mathrm{C}_{15} \mathrm{H}_{20} \mathrm{O}_{9}+\mathrm{H}\right]^{+}$ $(\mathrm{m} / \mathrm{z}=345.1186)$

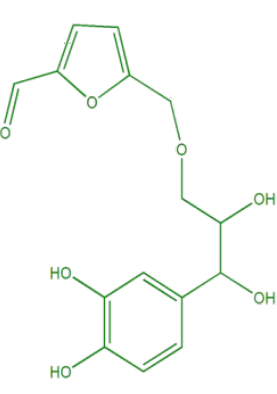

$\left[\mathrm{C}_{15} \mathrm{H}_{16} \mathrm{O}_{8}+\mathrm{H}\right]^{+}$ $(\mathrm{m} / \mathrm{z}=325.0923)$

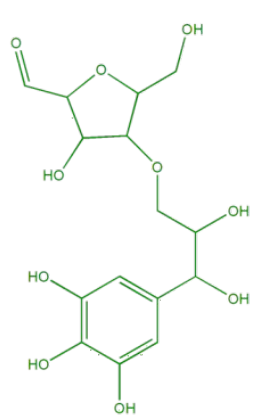

$\left[\mathrm{C}_{15} \mathrm{H}_{20} \mathrm{O}_{10}+\mathrm{H}\right]^{+}$ $(\mathrm{m} / \mathrm{z}=361.1134)$

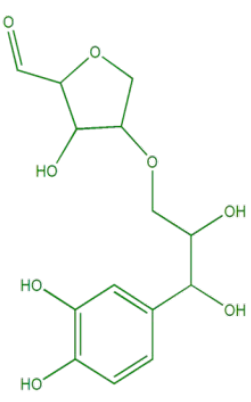

$\left[\mathrm{C}_{14} \mathrm{H}_{18} \mathrm{O}_{9}+\mathrm{H}\right]^{+}$ $(\mathrm{m} / \mathrm{z}=331.1029)$

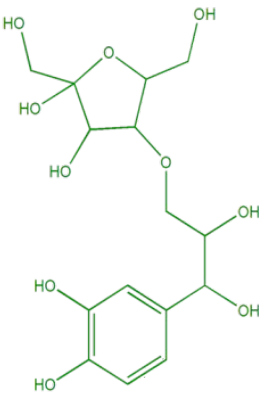

$\left[\mathrm{C}_{15} \mathrm{H}_{22} \mathrm{O}_{10}+\mathrm{H}\right]^{+}$ $(\mathrm{m} / \mathrm{z}=363.1291)$

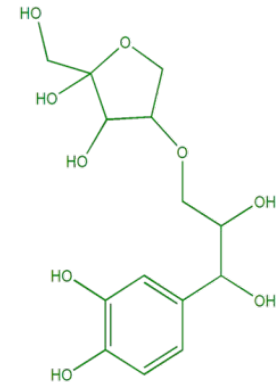

$\left[\mathrm{C}_{16} \mathrm{H}_{12} \mathrm{O}_{5}+\mathrm{H}\right]^{+}$ $(\mathrm{m} / \mathrm{z}=333.1185)$

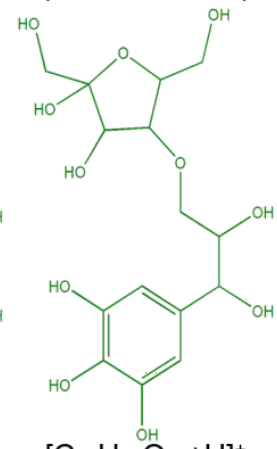

$\left[\mathrm{C}_{15} \mathrm{H}_{22} \mathrm{O}_{11}+\mathrm{H}\right]^{+}$ $(\mathrm{m} / \mathrm{z}=379.1240)$

Figure S8. Lignin-carbohydrate-complex (LCC) detected from ESI-MS spectra.

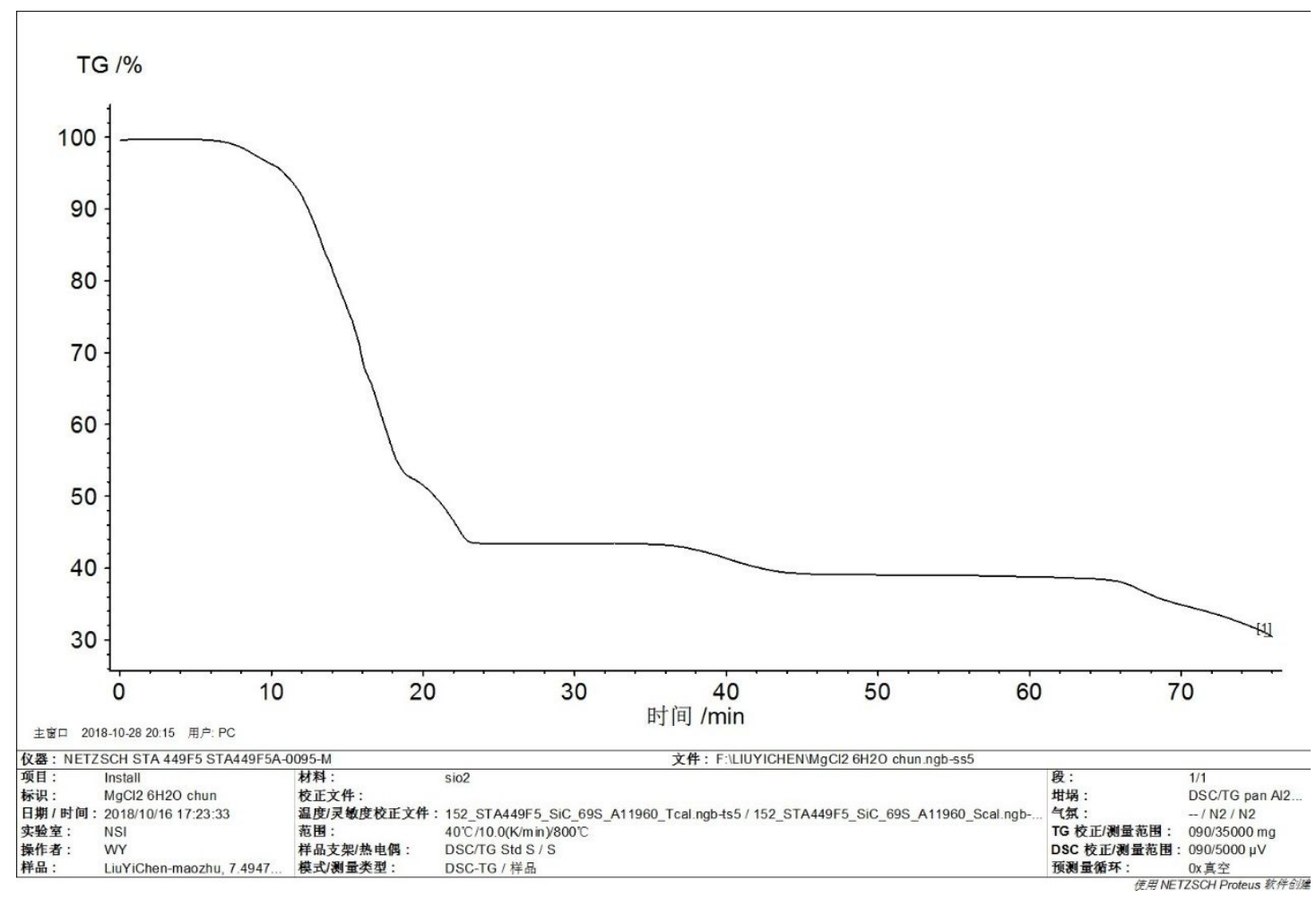

Figure S9. TG curve of pure $\mathrm{MgCl} 2 \cdot 6 \mathrm{H} 2 \mathrm{O}$. 


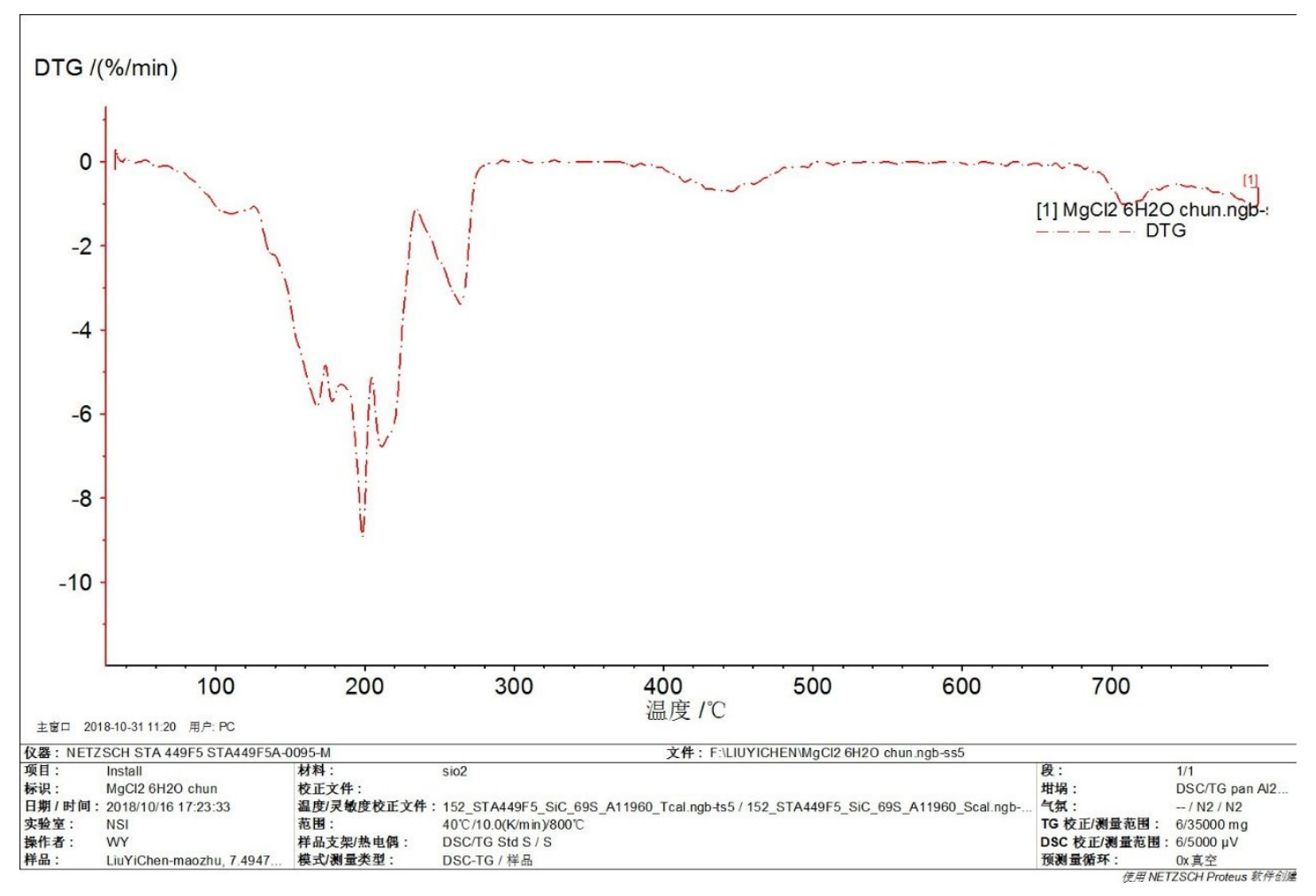

Figure S10. DTG curve of pure $\mathrm{MgCl} 2 \cdot 6 \mathrm{H} 2 \mathrm{O}$.

Table S1. Content analysis of raw pubescens.

\begin{tabular}{llll}
\hline Titration analysis & $(\%)$ & Proximate analysis & $(\%)$ \\
\hline Cellulose & 43.0 & Fixed carbon & 3.1 \\
Hemicellulose & 19.5 & Volatile matter & 90.3 \\
Lignin & 21.3 & Ash content & 0.5 \\
& & Moisture & 6.2 \\
Content of inorganic & $(\%)$ & & \\
elements & & & \\
$\mathrm{Al}$ & 0.00 & Elemental analysis & $(\%)$ \\
$\mathrm{Ca}$ & 0.04 & $\mathrm{C}$ & 49.4 \\
$\mathrm{Cu}$ & 0.00 & $\mathrm{H}$ & 5.7 \\
$\mathrm{Fe}$ & 0.05 & $\mathrm{O}$ & 44.1 \\
$\mathrm{~K}$ & 0.18 & $\mathrm{~N}$ & 0.8 \\
$\mathrm{Mg}$ & 0.23 & & \\
$\mathrm{Mn}$ & 0.01 & & \\
$\mathrm{Na}$ & 0.08 & & \\
$\mathrm{Zn}$ & 0.00 & & \\
\hline
\end{tabular}


Table S2. Mg contents of pubescens samples.

\begin{tabular}{ccccccc}
\hline Samples & Raw & 0 wt.\% & 5 wt. $\%$ & 10 wt. $\%$ & 15 wt.\% & 20 wt. $\%$ \\
\hline $\begin{array}{c}\text { Mg content } \\
\text { / } \%\end{array}$ & & 0.03 & 1.76 & 3.33 & 4.31 & 6.04 \\
\hline
\end{tabular}

Table S3. Retention time of compounds in GC-FID.

\begin{tabular}{|l|l|}
\hline Compounds & Retention time /min \\
\hline furfural & 5.861 \\
\hline furfuryl alcohol & 6.289 \\
\hline benzyl alcohol & 11.270 \\
\hline o-cresol & 11.878 \\
\hline p-cresol & 12.682 \\
\hline guaiacol & 13.115 \\
\hline 4-ethylphenol & 15.390 \\
\hline eugenol & 21.008 \\
\hline 4-methyl-2,6-dimethoxyphenol & 23.683 \\
\hline isoeugenol & \\
\hline 4-allyl-2,6-dimethoxyphenol & 23.833 \\
\hline
\end{tabular}

Table S4. Retention time of compounds in HPLC.

\begin{tabular}{|l|l|}
\hline Compounds & Retention time $/ \mathrm{min}$ \\
\hline formic acid & 13.560 \\
\hline acetic acid & 14.813 \\
\hline HMF & 30.833 \\
\hline
\end{tabular}

Table S5. Calibration table of GPC

\begin{tabular}{|l|l|l|}
\hline Elution Volume/ $\mathrm{mL}$ & $\mathrm{Mp} / \mathrm{mL}$ & Polymer Lot No. \\
\hline 1,77 & 15700 & $\mathrm{ps} 1088$ \\
\hline 1,82 & 9130 & $\mathrm{ps} 21061$ \\
\hline 1,88 & 6540 & $\mathrm{ps} 180213$ \\
\hline 1,95 & 4920 & $\mathrm{ps} 20125$ \\
\hline 2,06 & 3470 & $\mathrm{ps} 6126$ \\
\hline 2,24 & 2280 & $\mathrm{ps} 13124$ \\
\hline 2,42 & 1410 & $\mathrm{ps} 171209$ \\
\hline 2,45 & 1306 & $\mathrm{ps} 171209$ \\
\hline 2,48 & 1202 & $\mathrm{ps} 171209$ \\
\hline 2,51 & 1098 & $\mathrm{ps} 171209$ \\
\hline
\end{tabular}




\begin{tabular}{|l|l|l|}
\hline 2,54 & 994 & ps171209 \\
\hline 2,59 & 890 & ps270710 \\
\hline 2,63 & 786 & ps270710 \\
\hline 2,67 & 682 & ps270710 \\
\hline 2,72 & 578 & ps270710 \\
\hline 2,78 & 474 & ps270710 \\
\hline 2,84 & 370 & ps270710 \\
\hline 2,93 & 226 & psp2-4 \\
\hline
\end{tabular}

Detailed process of Van Soest titration:

1. Determination of cellulose content.

The air-dried bamboo samples were milled into powder of 40-60 mesh.

Sample (0.05-0.06 g) was put into a centrifuge tube, and then $5 \mathrm{ml} \mathrm{HNO}-\mathrm{HAc}$ mixed solution was added. The mixture was heated in boiling water for $25 \mathrm{~min}$ with stirring. Then the mixture was centrifuged. The supernatant was decanted, and the precipitate was washed with distilled water for three times. The washed precipitate was added to $10 \mathrm{ml} 0.5 \mathrm{M} \mathrm{K} 2 \mathrm{Cr}_{2} \mathrm{O} 7$ and $8 \mathrm{ml} 98 \%$ $\mathrm{H}_{2} \mathrm{SO} 4$ solution before heating in boiling water for $10 \mathrm{~min}$ with stirring. Then the reaction mixture was cooled to room temperature, and then transferred into a $250 \mathrm{ml}$ Erlenmeyer flask. Three drops of $0.2 \% \mathrm{C}_{6} \mathrm{H}_{5} \mathrm{NHC}_{6} \mathrm{H}_{4} \mathrm{COOH}$ indicator was added, and then the mixture was titrated with $0.1 \mathrm{M}$ (NH4)2SO4-FeSO 4 solution to the end point. A blank experiment was also performed. The cellulose content, $\mathrm{x} \%$, in the bamboo sample was calculated as follows

$$
\begin{gathered}
\mathrm{K}=25 \times 0.1 / \mathrm{m} \\
\mathrm{x} \%=0.675 \times \mathrm{K}(\mathrm{a}-\mathrm{b}) / \mathrm{n}
\end{gathered}
$$

where $\mathrm{K}$ is the titer of $0.1 \mathrm{M}\left(\mathrm{NH}_{4}\right)_{2} \mathrm{SO}_{4} \cdot \mathrm{FeSO} 4$ solution, $m$ is the volume of $25 \mathrm{ml} 0.1 \mathrm{M} \mathrm{K}_{2} \mathrm{Cr}_{2} \mathrm{O} 7$ standard solution for demarcating titer, a is the volume of $0.1 \mathrm{M}\left(\mathrm{NH}_{4}\right)_{2} \mathrm{SO} 4 \cdot \mathrm{FeSO} 4$ solution for the blank experiment, $\mathrm{b}$ is the volume of $0.1 \mathrm{M}\left(\mathrm{NH}_{4}\right)_{2} \mathrm{SO} 4 \cdot \mathrm{FeSO} 4$ solution for the sample, and $\mathrm{n}$ is the sample weight.

2. Determination of hemi-cellulose content.

About $0.1-0.2 \mathrm{~g}$ air-dried bamboo powder was put into a $100 \mathrm{ml}$ glass beaker to which $15 \mathrm{ml} 80 \%$ $\mathrm{Ca}\left(\mathrm{NO}_{3}\right)_{2}$ solution was added. Then the glass beaker was covered and heated for $5 \mathrm{~min}$ on a hot plate. The reaction mixture was centrifuged. The supernatant was decanted, and the precipitate was washed with hot distilled water for three times. The precipitate was added to $10 \mathrm{ml} 2 \mathrm{M} \mathrm{HCl}$ solution and heated in a boiling water-bath for $45 \mathrm{~min}$ with stirring. The mixture was centrifuged again to separate the supernatant and the precipitate, which was washed with distilled water for three times, and then the mixture solution, i.e., the supernatant and the three washes, was transferred into a $100 \mathrm{ml}$ volumetric flask after neutralization with $2 \mathrm{M} \mathrm{NaOH}$ solution, diluted with water to the $100 \mathrm{ml} \mathrm{scale}$, and then filtered. To an aliquot of $10 \mathrm{ml}$ filtrate, Solution A was added, and heated in a boiling water-bath for $15 \mathrm{~min}$. Then, $5 \mathrm{ml}$ mixed solution of oxalic acid and sulfuric acid solution and $0.5 \mathrm{ml} \mathrm{5 \%}$ starch were added before titrated with $0.01 \mathrm{M} \mathrm{Na} 2 \mathrm{~S}_{2} \mathrm{O}_{3}$ 
solution to the end point. A blank experiment was also performed. The hemi-cellulose content, $x \%$, in the bamboo sample was calculated as

$$
x \%=0.9 \times 100[248-(a-b)](a-b) / 10000 \times 10 \times n
$$

where $a$ is the volume of $0.01 \mathrm{M} \mathrm{Na}_{2} \mathrm{~S}_{2} \mathrm{O}_{3}$ solution for the blank experiment, $b$ is the volume of $0.01 \mathrm{M} \mathrm{Na} 2 \mathrm{~S}_{2} \mathrm{O} 3$ solution for the sample, and $n$ is the sample weight.

3. Determination of lignin content.

$0.05-0.10 \mathrm{~g}$ air-dried bamboo powder was put into a centrifuge tube and $10 \mathrm{ml} 1 \%$ acetic acid solution was added. Then, the mixture was centrifuged. The supernatant was decanted, and the precipitate was washed with $5 \mathrm{ml} 1 \%$ acetic acid and $3 \mathrm{ml}$ acetone thrice. The precipitate was dispersed on the wall of the centrifuge tube and dried in the water-bath. $3 \mathrm{ml} 73 \% \mathrm{H}_{2} \mathrm{SO} 4$ was added to the dried precipitate with stirring, and the mixture was left to stand for $24 \mathrm{~h}$. Then, $10 \mathrm{ml}$ distilled water was added to the mixture before it was heated for $5 \mathrm{~min}$ in boiling water. The mixture was cooled to room temperature, and then $0.5 \mathrm{ml} 10 \% \mathrm{BaCl}_{2}$ solution was added and stirred to mix well. Then the mixture was centrifuged, the supernatant was decanted, and the precipitate was washed with distilled water twice. The washed precipitate was added to $10 \mathrm{ml} 0.5$ $\mathrm{M} \mathrm{K}_{2} \mathrm{Cr}_{2} \mathrm{O}_{7}$ and $8 \mathrm{ml} 98 \% \mathrm{H}_{2} \mathrm{SO}_{4}$ solution before heating in boiling water for $15 \mathrm{~min}$ with stirring. Then the mixture was cooled to room temperature again, and transferred into a $250 \mathrm{ml}$ Erlenmeyer flask. Three drops of $0.2 \% \mathrm{C}_{6} \mathrm{H}_{5} \mathrm{NHC} 6 \mathrm{H} 4 \mathrm{COOH}$ indicator was added, then titrated with $0.1 \mathrm{M}$ (NH4)2SO4-FeSO4 solution to the end point. A blank experiment was also performed. The lignin content, $x \%$, in the bamboo sample was calculated as

$$
\begin{gathered}
K=25 \times 0.1 / \mathrm{m} \\
x \%=0.433 \times K(a-b) / n
\end{gathered}
$$

where $K$ is the titer of $0.1 \mathrm{M}\left(\mathrm{NH}_{4}\right) 2 \mathrm{SO} 4 \cdot \mathrm{FeSO} 4$ solution, $\mathrm{m}$ is the volume of $25 \mathrm{ml} 0.1 \mathrm{M} \mathrm{K}_{2} \mathrm{Cr}_{2} \mathrm{O} 7$ standard solution for demarcating titer, $a$ is the volume of $0.1 \mathrm{M}\left(\mathrm{NH}_{4}\right)_{2} \mathrm{SO}_{4} \cdot \mathrm{FeSO} 4$ solution for the blank experiment, $b$ is the volume of $0.1 \mathrm{M}\left(\mathrm{NH}_{4}\right)_{2} \mathrm{SO} 4 \cdot \mathrm{FeSO} 4$ solution for the sample, and $n$ is the sample weight. 